\title{
ANALISIS PERBANDINGAN KINERJA REKSADANA SAHAM MENGGUNAKAN METODE SHARPE DAN TREYNOR PADA REKSADANA SAHAM
}

\author{
Clara Bella \\ Yul Tito Permadhy \\ Universitas Pembangunan Nasional "Veteran" Jakarta \\ claraelizabeth71@gmail.com
}

\begin{abstract}
This study aims to determine the comparison of stock mutual fund performance using sharpe method and treynor method. The research method used in this research is descriptive method with quantitative approach. The object of this study using all mutual fund shares listed on the Indonesia Stock Exchange period 2013-2016. The technique of determining the sample using purposive sampling method so that 66 mutual funds were chosen as research sample. The results of this study explain that there are differences in the results of the performance of stock mutual funds using sharpe method and treynor method on mutual fund shares listed on the Indonesia Stock Exchange (BEI) where each performance value fluctuates in the period 20132016. The results show that only a few stock mutual funds are above market performance by using sharpe method and treynor method during the period 2013-2016. The results show that only one stock mutual fund that has consistent performance above market performance during the period 2013-2016 using the sharpe method of equity fund Sam Equity Fund.
\end{abstract}

Keywords : Stock Mutual Funds, Portfolio Performance, Sharpe Method, Treynor Method, Return, And Risk.

\section{PENDAHULUAN}

\subsection{Latar Belakang Penelitian}

Perkembangan pasar modal yang semakin maju, belum disertai dengan kesadaran masyarakat untuk berinvestasi. Minimnya pengetahuan masyarakat tentang investasi dalam pasar modal membuat mereka lebih tertarik menyetorkan uangnya pada bank dalam bentuk tabungan atau deposito.

Untuk mengatasi masalah tersebut, maka pasar modal menyediakan salah satu instrument investasi yaitu reksadana. Reksadana merupakan wadah bagi masyarakat pemodal untuk menginvestasikan dananya yang kemudian akan dikelola oleh manajer investasi.

Investasi dalam reksadana tidak membutuhkan dana yang cukup besar sehingga cocok bagi investor pemula yang memiliki sedikit dana. Reksadana juga dikelola oleh manajer investasi sehingga memudahkan investor pemula yang tidak memiliki banyak waktu dan pengetahuan untuk mengelola dananya secara langsung pada instrument investasi. Selain itu investasi reksadana yang diperdagangkan pasar modal memiliki berbagai jenis seperti reksadana pendapatan tetap, reksadana saham, reksadana pasar uang, reksadana campuran, dan reksadana syariah, sehingga banyaknya jenis reksadana dapat memudahkan investor dalam memilih investasi tergantung kebutuhan investor itu sendiri.

Pada setiap investasi, investor mengharapkan tingkat pengembalian (return) yang tinggi dari dana yang telah diinvestasikannya. Return yang dihasilkan pada reksadana dilihat dari Nilai Aktiva Bersih (NAB) dalam reksadana tersebut. Dari beberapa jenis reksadana yang diperdagangkan dalam pasar modal salah satunya adalah reksadana saham yang memiliki return yang tinggi dibandingkan dengan reksadana lainnya dan juga merupakan investasi jangka panjang. Reksadana ini memiliki return yang tinggi karena $80 \%$ dana investasi dialokasikan 
pada efek berupa saham dan sisanya dialokasikan dalam instrument pasar uang berupa deposito atau obligasi.

Dikutip dari bareksa.com, pada tahun 2016 return saham mengalami peningkatan terutama pada sektor pertambangan, sektor industri dasar, dan sektor manufaktur. Sehingga dalam hal ini manajer investasi selaku pengelola reksadana dituntut untuk dapat mengalokasikan dana investasi pada saham-saham yang mengalami peningkatan.

IHSG dan indeks reksadana saham mengalami fluktuasi selama tahun 2011-2016 dan cenderung bergerak ke arah positif. IHSG merupakan gambaran dari kondisi pasar maka dari itu return IHSG yang berfluktuasi kearah positif menandakan bahwa harga saham perusahaan yang tercatat pada Bursa Efek Indonesia (BEI) mengalami peningkatan. Tetapi hal tersebut tidak disertai dengan kondisi reksadana saham. Meskipun keduanya menunjukkan return yang bergerak kearah positif, pada pertengahan tahun 2016 return reksadana saham yaitu sebesar $21,39 \%$ masih berada dibawah IHSG yaitu sebesar $27,44 \%$. Ini berarti kondisi pasar yang meningkat tidak disertai dengan kinerja yang baik pada reksadana saham. Dapat dilihat juga, return dari 4 reksadana saham tahun 2016, yaitu sebagai berikut:

Tabel 1

Kinerja Reksadana Saham 2016

\begin{tabular}{clccc}
\hline No & \multicolumn{1}{c}{ Reksadana } & Return & Sharpe & Treynor \\
\hline \multirow{2}{*}{$1)$} & $\begin{array}{l}\text { Treasure Fund Super } \\
\text { Maxxi }\end{array}$ & $4.60 \%$ & $-0.30 \%$ & $-11.48 \%$ \\
\hline 2) & Sucorinvest Equity Fund & $4.48 \%$ & $-0.42 \%$ & $-12.27 \%$ \\
\hline 3$)$ & Axa Citradinamis & $0.94 \%$ & $-1.61 \%$ & $-5.79 \%$ \\
\hline 4$)$ & Danareksa Mawar & $1.04 \%$ & $-1.60 \%$ & $-5.87 \%$ \\
\hline
\end{tabular}

Sumber: Data diolah

Tabel di atas menjelaskan bahwa reksadana saham yang memiliki return tertinggi pada tahun 2016 adalah produk Treasure Fund Super Maxxi dengan return sebesar 4,60 \%, peringkat kedua adalah Sucorinvest Equity Fund sebesar 4,48\%, peringkat ketiga adalah Danareksa Mawar sebsesar 1,04\%, dan return terendah adalah produk Axa Citra Dinamis sebesar 0,94\%. Di lihat dari kinerja portofolio menggunakan metode sharpe dan metode treynor, keempat reksadana saham tersebut memiliki kinerja dengan hasil yang berbeda. Misalnya pada reksadana saham Treasure Fund Super Maxxi memiliki hasil kinerja dengan metode sharpe sebesar $0,30 \%$ sedangkan dengan metode treynor sebesar $-11,48 \%$. Pada reksadana saham Axa Citradinamis hasil kinerja dengan metode sharpe sebesar -1,61\% sedangkan dengan metode treynor sebesar $-5,79 \%$ Walaupun keempat reksadana saham tersebut memiliki return yang positif, namun kinerja portofolio dari reksadana saham tersebut memiliki hasil negatif selama tahun 2016 dengan kedua metode tersebut.

Pada setiap return yang dihasilkan, tentunya terdapat risiko yang harus dihadapi dalam investasi. Risiko pada reksadana saham misalnya penurunan Nilai Aktiva Bersih (NAB), hal ini dapat terjadi jika instrument dalam reksadana tersebut mengalami gejolak, misalnya harga saham yang bergerak rendah. Dalam menilai kinerja reksadana tidak cukup hanya dengan menghitung return portofolionya saja tetapi juga harus mempertimbangkan risiko dari investasi reksadana tersebut. Pengukuran kinerja portofolio reksadana yang mempertimbangkan faktor return dan risiko disebut dengan return sesuaian risiko (risk-adjusted return). Pengukuran kinerja portofolio reksadana dimaksudkan untuk menilai kinerja manajer investasi dalam mengelola aktiva dalam reksadana saham sesuai dengan kebijakan investasinya.

Pengukuran risk-adjusted return artinya bahwa return portofolio dalam reksadana yang dihitung harus disesuaikan dengan risiko yang ditanggung oleh investor. Karena pada dasarnya investor menginginkan bahwa risiko yang tinggi harus dapat menghasilkan return yang tinggi pula (high risk high return). Terdapat beberapa metode pengukuran kinerja portofolio, pada penelitian ini metode yang dipakai adalah metode sharpe dan metode treynor. Pengukuran 
menggunakan metode sharpe yaitu dengan membagi excess return dengan risiko total yang diukur dengan standar deviasi. Sedangkan metode treynor membagi excess return dengan risiko sistematis yang diukur dengan beta. Dalam menilai kinerja portofolio reksadana saham, dibutuhkan pembanding (benchmark) yaitu Indeks Harga Saham Gabungan (IHSG) sebagai kondisi pasar modal.

\subsection{Perumusan Masalah}

Rumusan masalah dari penelitian ini yaitu sebagai berikut:

a. Bagaimana perbandingan kinerja reksadana saham menggunakan metode sharpe dan treynor.

b. Apakah kinerja reksadana saham berada diatas kinerja pasar.

c. Reksadana saham apa saja yang memiliki kinerja yang konsisten.

\section{TINJAUAN PUSTAKA DAN PENGEMBANGAN HIPOTESIS}

\subsection{Pasar Modal}

Menurut Halim (2015, hlm. 1), menjelaskan bahwa 'pasar modal adalah pasar yang mempertemukan pihak yang menawarkan dan yang memerlukan dana jangka panjang'. Pada Undang-Undang Pasar Modal nomor 8 Tahun 1995 dalam Samsul (2015, hlm. 57), menjelaskan bahwa 'pasar modal sebagai kegiatan yang bersangkutan dengan penawaran umum dan perdagangan efek, perusahaan publik yang berkaitan dengan efek yang diterbitkannya, serta lembaga dan profesi yang berkaitan dengan efek'. Pasar modal memperdagangkan instrument investasi seperti saham, obligasi, waran, right, reksadana, dan berbagai instrument derivatif seperti opsi dan kontrak berjangka (Darmadji \& Fakhruddin, 2012 hlm. 2).

\subsection{Saham}

Menurut Fahmi (2015, hlm. 80), menjelaskan 'saham merupakan tanda bukti penyertaan kepemilikan modal atau dana pada suatu perusahaan yang tercantum nilai nominal, nama perusahaan dengan hak dan kewajiban bagi setiap pemegang saham'. Saham terdiri dari Saham Biasa (Common Stocks) dan Saham Preferen (Preferred Stocks).

\subsection{Keuntungan dan Risiko Memiliki Saham}

Keuntungan yang diperoleh pemodal dengan memiliki saham adalah Dividen : merupakan pembagian keuntungan yang diberikan perusahaan penerbit saham tersebut atas keuntungan yang dihasilkan perusahaan dan Capital gain. Sedangkan risiko yang dihadapi pemodal dengan memiliki saham antara lain tidak mendapat dividen, jika perusahaan mengalami kerugian.

\subsection{Reksadana}

Reksadana didefinisikan sebaga wadah yang dipergunakan untuk menghimpun dana dari masyarakat pemodal untuk selanjutnya diinvestasikan dalam portofolio efek oleh manajer investasi.

\subsection{Manfaat Reksadana}

Manfaat berinvestasi reksadana adalah investor yang tidak memiliki dana yang cukup besar, tetapi dapat melakukan diversifikasi investasi dalam efek, sehingga dapat memperkecil risiko, reksadana mempermudah pemodal untuk melakukan investasi di pasar modal, adanya efisiensi waktu dimana reksadana dikelola oleh manajer investasi 


\subsection{Risiko Reksadana}

Risiko reksadana antara lain risiko berkurangnya nilai unit penyertaan, risiko likuiditas dan wanprestasi.

\subsection{Nilai Aktiva Bersih (NAB)}

Nilai Aktiva Bersih (NAB) merupakan jumlah aset setelah dikurangi kewajiban-kewajiban yang ada'. Rumus untuk menghitung Nilai Aktiva Bersih (NAB) adalah sebagai berikut :

$$
\text { NAB }=\frac{\text { Nilai pasar aset }- \text { Liabilitas }}{\text { Jumlah saham beredar }}
$$

Tolak ukur kinerja NAB dapat dilihat dari nilai investasi portofolio reksadana, jika harga pasar aset-aset dalam reksadana meningkat maka NAB tentunya juga mengalami kenaikan (Darmadji \& Fakhruddin, 2012 hlm. 178).

\subsection{Jenis Reksadana}

Berdasarkan sifatnya, reksadana dapat dibedakan : Reksadana Bersifat Tertutup (ClosedEnd Fund) dan Reksadana Bersifat Terbuka (Open-End Fund)

\subsection{Return}

Return adalah imbal hasil atau keuntungan yang diperoleh dari hasil kebijakan investasi yang telah dilakukan'. Return dapat terbagi menjadi dua yaitu realized return dan expected return. Realized return adalah return yang telah terjadi dan juga berguna sebagai pengukur kinerja perusahaan karena dijadikan dasar perhitungan expected return dan risiko dimasa datang, sedangkan expected return adalah 'return yang diharapkan akan diperoleh oleh investor dimasa mendatang' (Hartono, 2015 hlm. 263). Menurut Hartono (2015, hlm. 265), return saham dirumuskan yaitu sebagai berikut:

$$
\text { Return Saham }=\frac{\mathbf{P}_{\mathrm{t}}-\mathbf{P}_{\mathrm{t}-1}+\mathbf{D}_{\mathrm{t}}}{\mathbf{P}_{\mathrm{t}-1}}
$$

Jika harga investasi sekarang $\left(\mathrm{P}_{\mathrm{t}}\right)$ lebih tinggi dari harga investasi periode lalu $\left(\mathrm{P}_{\mathrm{t}-1}\right)$ ini berarti terjadi keuntungan modal (capital gain), tetapi bila terjadi sebaliknya maka terjadi kerugian modal (capital loss). Yield $\left(\mathrm{D}_{\mathrm{t}}\right)$ merupakan penerimaan kas periodik terhadap harga saham periode sebelumnya.

Menurut Markowitz dalam Zubir (2013, hlm.2), menjelaskan 'bahwa dalam memaksimumkan expected return saham, investor dapat melalui diversifikasi sekuritas dalam portofolio'. Return realisasi portofolio merupakan rata-rata tertimbang dari return realisasi masing-masing sekuritas tunggal dalam portofolio, maka rumus yang digunakan adalah sebagai berikut (Hartono, $2015 \mathrm{hlm} .312$ ):

$$
\mathbf{R} p=\sum_{\mathrm{i}=1}^{\mathrm{n}}\left(\mathbf{W}_{\mathrm{i}} \cdot \mathbf{R}_{\mathrm{i}}\right)
$$

Sedangkan expected return portofolio merupakan rata-rata tertimbang dari expected return masing-masing sekuritas tunggal dalam portofolio, maka rumus yang digunakan adalah sebagai berikut:

$$
E(R P)=\sum_{i=1}^{n}\left(W_{i} \cdot E\left(R_{i}\right)\right)
$$


Pada reksadana, rumus yang digunakan untuk menghitung return portofolio adalah sebagai berikut (Hartono, 2015 hlm.705):

$$
\text { Return }=\frac{\mathrm{NAB}_{\mathrm{t}}-\mathbf{N A B}_{\mathrm{t}-}}{\mathbf{N A B}_{\mathrm{t}-1}}
$$

Berdasarkan rumus diatas, Nilai Aktiva Bersih $\left(\mathrm{NAB}_{t}\right)$ merupakan nilai portofolio periode sekarang, sedangkan $\mathrm{NAB}_{\mathrm{t}-1}$ merupakan nilai portofolio periode tahun lalu. Dalam menilai kinerja portofolio dibutuhkan pembanding (benchmark), benchmark tersebut dalam Bursa Efek Indonesia (BEI) adalah Indeks Harga Saham Gabungan (IHSG). IHSG merupakan indeks yang menggunakan semua saham yang tercatat sebagai komponen perhitungan. Maka rumus untuk menghitung return pasar $\left(\mathrm{R}_{\mathrm{M}}\right)$ adalah sebagai berikut (Fahmi, 2015 hlm.188):

$$
\mathbf{R}_{\mathbf{M}}=\frac{\text { IHSG }_{\mathrm{t}}-\mathbf{I H S G}_{\mathrm{t}-\mathbf{1}}}{\text { IHSG }_{\mathrm{t}-1}}
$$

\subsection{Risiko}

Resiko adalah besarnya penyimpangan tingkat pengembalian yang diharapkan (expected return) dengan tingkat pengembalian yang dicapai secara nyata (actual return)'.

\subsection{Pengukuran Risiko}

Untuk menghitung hitung risiko, metode yang banyak digunakan adalah standar deviasi (standart deviation) yang mengukur risiko yang terjadi dengan return yang diharapkan. Risiko juga dapat disebut varian yaitu kuadrat dari standar deviasi, sehingga rumus varian adalah sebagai berikut (Halim, 2015 hlm. 52):

$$
\sigma i^{2}=\frac{\sum_{j=1}^{n}\left\{R_{i j}-\mathbf{E}\left(R_{i}\right)\right\}^{2}}{N}
$$

Maka rumus standar deviasi yang dihitung adalah sebagai berikut:

$$
\sigma i=\sqrt{\frac{\sum_{j=1}^{n}\left\{R_{i j}-\mathbf{E}\left(R_{i}\right)\right\}^{2}}{N}}
$$

Untuk menghitung besaran risiko dari return pasar terhadap rata-rata expected return pasar pada periode tertentu, maka rumus varian pasar yang digunakan adalah sebagai berikut (Halim, 2015 hlm. 82):

$$
\sigma \mathbf{m}^{2}=\sum_{\mathrm{i}=1}^{\mathrm{n}} \frac{\left(\mathrm{R}_{\mathrm{m}}-\overline{\mathbf{R}_{\mathrm{m}}}\right)^{2}}{\mathrm{~N}}
$$

\subsection{Beta}

Beta merupakan pengukur risiko sistematik dari suatu sekuritas terhadap risiko pasar, yang dapat diestimasi dengan mengumpulkan historis return dari sekuritas dan return pasar selama periode tertentu (Hartono, 2015 hlm.445). Beta dapat dihitung dengan rumus adalah sebagai berikut:

$$
\boldsymbol{\beta}_{\mathrm{i}}=\frac{\sum_{\mathrm{t}=1}^{\mathrm{n}}\left(\mathbf{R}_{\mathrm{it}}-\overline{\mathbf{R}_{\mathrm{it}}}\right)\left(\mathbf{R}_{\mathrm{Mt}}-\overline{\mathbf{R}_{\mathrm{Mt}}}\right)}{\sum_{\mathrm{t}=1}^{\mathrm{n}}\left(\mathbf{R}_{\mathrm{Mt}}-\overline{\mathbf{R}_{\mathrm{Mt}}}\right)^{2}}
$$


atau dapat diringkas sebagai berikut:

$$
\beta_{i}=\frac{\sigma_{\mathrm{iM}}}{\sigma^{2} M}
$$

Menurut Darmadji dan Fakhruddin (2012, hlm.162), beta menggambarkan sensitifitas atau kecenderungan respon suatu saham terhadap pasar. Penilaian beta dapat dikategorikan menjadi tiga kondisi berikut (Fahmi, 2015 hlm.189):

a. $\beta>1$ menunjukkan bahwa harga saham perusahaan lebih mudah berubah dibandingkan indeks pasar.

b. $\beta<1$ menunjukkan bahwa tidak mudah terjadi perubahan akibat kondisi pasar.

c. $\beta=1$ menunjukkan bahwa besarnya risiko sistematis sama seperti indeks pasar.

\subsection{Kinerja Portofolio}

Hal yang terpenting bagi manajer investasi maupun investor dari proses investasi saham adalah melakukan penilaian kinerja pada portofolio, tujuannya adalah untuk mengetahui apakah portofolio yang dibentuk sudah sesuai dengan tujuan investasi dengan menghitung return dan risiko dari portofolio tersebut (Halim, 2015 hlm.69). Return yang telah dihitung tersebut disesuaikan dengan risiko yang ditanggung yang dimana pengukuran kinerja portofolio ini disebut dengan return sesuaian-risiko (risk-adjusted return) (Hartono, $2015 \mathrm{hlm} .708$ ).

Metode-metode yang digunakan untuk menilai kinerja portofolio pada umumnya adalah metode sharpe dan metode treynor'.

\section{Metode Sharpe dan Metode Treynor}

Metode sharpe membagi rata-rata return lebih (selisih return portofolio dengan return bebas risiko) portofolio selama periode tertentu dengan standar deviasi sebagai risiko'. Metode ini disebut juga dengan nama reward to variability (RVAR) yang dikenalkan oleh William F. Sharpe pada tahun 1966 (Hartono, 2015 hlm. 709). Metode sharpe dihitung dengan rumus sebagai berikut:

$$
\text { RVAR }=\frac{\overline{T R_{p}}-\overline{R_{B R}}}{\sigma_{p}}
$$

Dalam mendapatkan portofolio yang terbaik, portofolio yang dihitung dengan metode sharpe diurutkan dari yang terbesar hingga terkecil sehingga didapatkan portofolio yang terbesar tersebut memiliki kinerja terbaik (Zubir, 2013 hlm.252).

Metode treynor merupakan kinerja portofolio dengan membagi return lebih (excess return) dengan risiko sistematis. Pengukuran ini mengasumsikan bahwa portofolio yang terbentuk sudah terdiversifikasi dengan baik, sehingga risiko yang ada dalam portofolio hanyalah risiko sistematik (systematic risk) yang diukur dengan beta (Zubir, $2013 \mathrm{hlm} .257$ ). Metode treynor dihitung dengan rumus sebagai berikut:

$$
\text { RVOL }=\frac{\overline{T_{P}}-\overline{R_{B R}}}{\beta_{P}}
$$

Semakin besar hasil excess return terhadap beta dalam pengukuran metode treynor, maka dapat dikatakan bahwa semakin baik kinerja portofolionya (Halim, 2015 hlm.71). 


\subsection{Kerangka Penelitian}

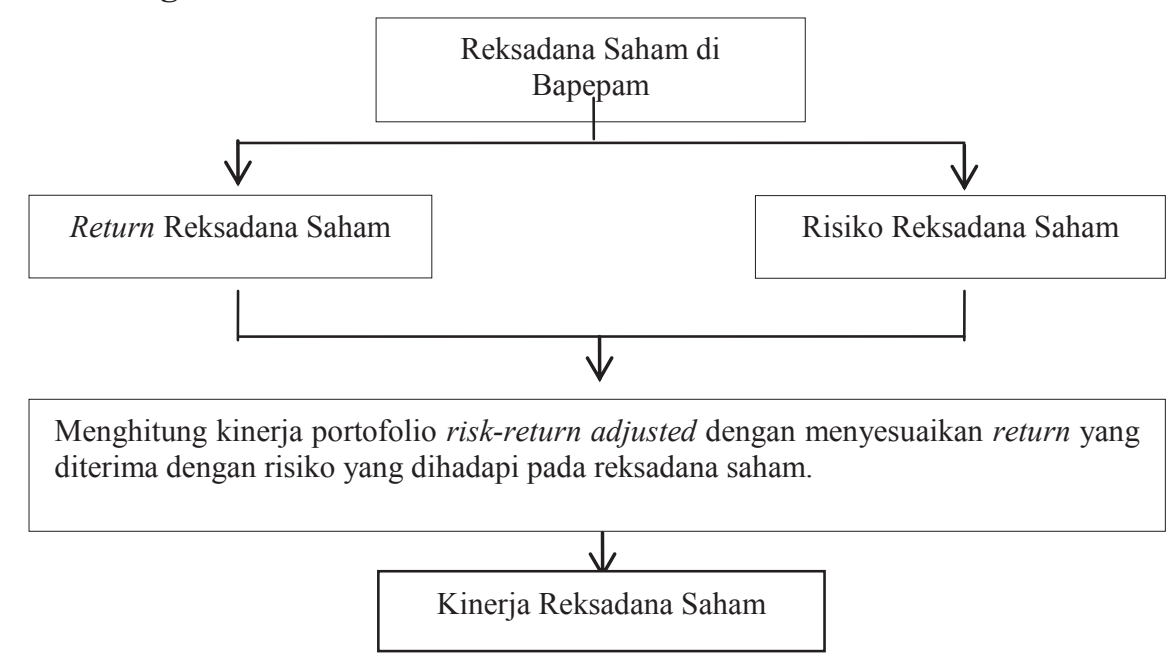

\section{METODE PENELITIAN}

\subsection{Definisi Operasional dan Pengukuran Variabel}

Definisi operasional dan pengukuran pada variabel yang digunakan dalam penelitian ini adalah sebagai berikut:

a. Return reksadana $\left(\mathrm{NAB}_{\mathrm{t}}\right)$, merupakan return portofolio dalam reksadana yang dihitung dari Nilai Aktiva Bersih (NAB). Rumus yang digunakan adalah sebagai berikut:

Keterangan:

$$
\text { Return }=\frac{\mathbf{N A B}_{\mathrm{t}}-\mathbf{N A B}_{\mathrm{t}-1}}{\mathrm{NAB}_{\mathrm{t}-1}}
$$

$\mathrm{NAB}_{\mathrm{t}} \quad=$ Nilai Aktiva Bersih periode sekarang

$\mathrm{NAB}_{\mathrm{t}-1} \quad=$ Nilai Aktiva Bersih periode tahun lalu

Hasil dari perhitungan return reksadana digunakan untuk dimasukan pada rumus kinerja portofolio yaitu metode sharpe dan metode treynor.

b. Return pasar $\left(\mathrm{R}_{\mathrm{m}}\right)$, merupakan imbal hasil atau keuntungan yang terdapat pada seluruh saham di Bursa Efek Indonesia (BEI). Return pasar yang digunakan sebagai benchmark adalah Indeks Harga Saham Gabungan (IHSG). Rumus yang digunakan adalah sebagai berikut:

Keterangan:

$$
\mathbf{R}_{\mathrm{M}, \mathrm{t}}=\frac{\text { IHSG }_{\mathrm{t}}-\mathbf{I H S G}_{\mathrm{t}-1}}{\text { IHSG }_{\mathrm{t}-1}}
$$

$\mathrm{IHSG}_{\mathrm{t}}=$ Indeks Harga Saham Gabungan periode sekarang

$\mathrm{IHSG}_{\mathrm{t}-1}=$ Indeks Harga Saham Gabungan tahun lalu

Hasil perhitungan return pasar digunakan sebagai pembanding (benchmark) dengan hasil metode sharpe dan metode treynor.

c. Varians pasar $\left(\sigma_{\mathrm{M}}^{2}\right)$ merupakan besaran risiko dari return pasar terhadap rata-rata expected return pasar pada periode tertentu. Rumus yang digunakan adalah sebagai berikut :

$$
\sigma \mathrm{m}^{2}=\sum_{\mathrm{i}=1}^{\mathrm{n}} \frac{\left(\mathrm{R}_{\mathrm{m}}-\overline{\mathrm{R}_{\mathrm{m}}}\right)^{2}}{\mathrm{~N}}
$$

Keterangan:

$$
\begin{array}{ll}
\sigma^{2} & =\text { varians return pasar } \\
\mathrm{Rm} & =\text { return pasar }
\end{array}
$$


$\overline{\mathrm{Rm}} \quad=$ rata-rata return pasar

$\mathrm{N} \quad=$ periode pengamatan

Hasil dari perhitungan varians return pasar digunakan untuk menghitung risiko sistematis yaitu beta $(\beta)$.

d. Standar deviasi $(\sigma)$, merupakan ukuran risiko total yang dihadapi oleh perusahaan. Rumus yang digunakan adalah sebagai berikut:

$$
\sigma i=\sqrt{\frac{\sum_{j=1}^{n}\left\{R_{i j}-E\left(R_{i}\right)\right\}^{2}}{N}}
$$

Keterangan:

$\mathrm{R}_{\mathrm{ij}} \quad=$ Return pada periode pengamatan

$\mathrm{E}\left(\mathrm{R}_{\mathrm{i}}\right) \quad=$ Expected Return pada pengamatan

$\mathrm{N} \quad=$ Periode pengamatan

Hasil dari perhitungan dari standar deviasi digunakan untuk dimasukan pada rumus kinerja portofolio yaitu metode sharpe.

e. Beta $(\beta)$, merupakan ukuran risiko sistematis (systematic risk) yang dihadapi seluruh perusahaan yang disebut juga risiko pasar (market risk). Rumus yang digunakan adalah sebagai berikut:

$$
\beta_{i}=\frac{\sum_{t=1}^{n}\left(R_{i t}-\overline{\mathbf{R}_{i t}}\right)\left(R_{M t}-\overline{\mathbf{R}_{M t}}\right)}{\sum_{t=1}^{n}\left(R_{M t}-\overline{R_{M t}}\right)^{2}}
$$

Keterangan:

$\mathrm{R}_{\text {it }} \quad=$ Return portofofolio

$\overline{\mathrm{R}_{\text {it }}} \quad=$ Rata-rata return portofolio

$\mathrm{R}_{\mathrm{Mt}} \quad=$ return pasar

$\overline{\mathrm{R}_{\mathrm{Mt}}} \quad=$ rata-rata return pasar

Atau dapat disederhanakan sebagai berikut:

$\beta_{i}=\frac{\sigma_{i M}}{\sigma^{2} M}$

Keterangan:

$\sigma_{\mathrm{iM}} \quad=$ Kovarians pasar

$\sigma^{2} \mathrm{M} \quad=$ Varians pasar

Hasil dari perhitungan dari standar deviasi digunakan untuk dimasukan pada rumus kinerja portofolio yaitu metode sharpe.

f. Return Bebas Risiko atau Risk Free Rate $\left(\mathrm{R}_{\mathrm{BR}}\right)$, merupakan tingkat pengambilan dari investasi yang tidak memiliki risiko yang didapat dari tingkat suku bunga Bank Indonesia (BI rate) yang didapatkan dari www.bi.go.id. Rumus yang digunakan adalah:

\section{$\mathbf{R B R}=\underline{\Sigma B I}$ Rate}

$\mathbf{n}$

Keterangan:

$\sum$ BI Rate = Jumlah BI Rate

$\mathrm{n} \quad=$ Periode pengamatan

Hasil dari perhitungan return bebas risiko digunakan pada rumus kinerja portofolio yaitu metode sharpe dan metode treynor.

\subsection{Populasi dan Sampel}

Populasi yang digunakan pada penelitian ini adalah seluruh reksadana saham yang terdaftar di Bursa Efek Indonesia (BEI) pada periode 2013-2016. 
Sampel merupakan bagian dari populasi. Teknik pengambilan sampel pada penelitian ini menggunakan purposive sampling yaitu mengambil sampel sesuai dengan kriteria penelitian. Maka kriteria pengambilan sampel pada penelitian ini adalah sebagai berikut: Reksadana saham konvensional yang terdaftar di Bursa Efek Indonesia (BEI), saham yang mempublikasi NAB dalam satuan rupiah, saham yang aktif selama periode 2013-2016, saham yang menerbitkan Nilai Aktiva Bersih (NAB) per bulan secara berturut-turut selama periode 2013-2016.

\subsection{Teknik Analisis dan Uji Hipotesis \\ Teknik Analisis}

Teknik analisis data yang dilakukan untuk menilai kinerja portofolio dalam reksadana saham dengan menggunakan risk-adjusted return adalah metode sharpe dan metode treynor. Data yang diolah merupakan data NAB reksadana saham, data IHSG, dan BI rate. Data-data yang dianalisis dan dihitung menggunakan program Microsoft Excel. Langkah-langkah dalam menilai kinerja portofolio dengan metode sharpe dan metode treynor adalah sebagai berikut:

Menghtung return dari Nilai Aktiva Bersih (NAB) reksadana saham yang hasil perhitungannya tersebut akan dimasukan dalam metode sharpe dan metode treynor

Keterangan:

$$
\text { Return }=\frac{\mathbf{N A B}_{\mathrm{t}}-\mathbf{N A B}_{\mathrm{t}-1}}{\mathrm{NAB}_{\mathrm{t}-1}}
$$

$\mathrm{NAB}_{\mathrm{t}} \quad=$ nilai portofolio periode sekarang

$\mathrm{NAB}_{\mathrm{t}-} \quad=$ nilai portofolio periode sebelumnya

Menghitung return IHSG sebagai pembanding (benchmark) dengan hasil kinerja portofolio dalam reksadana saham.

$$
\mathbf{R}_{\mathrm{M}}=\frac{\mathrm{IHSG}_{\mathrm{t}}-\mathrm{IHSG}_{\mathrm{t}-}}{\text { IHSG }_{\mathrm{t}-1}}
$$

Keterangan:

$\mathrm{R}_{\mathrm{M}}=$ return pasar

$\mathrm{IHSG}_{\mathrm{t}}=$ nilai IHSG periode sekarang

$\mathrm{IHSG}_{\mathrm{t}-1}=$ nilai IHSG periode sebelumnya

Menghitung rata-rata $\mathrm{BI}$ rate sebagai return bebas risiko (RBR) atau risk free rate (Rfr) yang digunakan untuk menghitung excess return dalam metode sharpe dan metode treynor.

\section{$\mathrm{RBR}=\frac{\sum \mathrm{BI} \text { Rate }}{\mathbf{n}}$}

Keterangan:

$\mathrm{RBR} \quad=$ return bebas risiko

$\Sigma$ BI Rate $=$ jumlah suku bunga BI

$\mathrm{n} \quad=$ periode pengamatan

Menghitung risiko berdasarkan varian untuk mendapatkan nilai standar deviasinya. Hasil dari perhitungan dari standar deviasi digunakan untuk dimasukan pada rumus kinerja portofolio yaitu metode sharpe.

$$
\sigma i^{2}=\frac{\sum_{j=1}^{n}\left\{R_{i j}-\mathbf{E}\left(\mathbf{R}_{\mathrm{i}}\right)\right\}^{2}}{\mathbf{N}}
$$

Keterangan:

$$
\begin{array}{ll}
\sigma \mathrm{i}^{2} & =\text { varians dari return } \\
\mathrm{R}_{\mathrm{ij}} & =\text { return pada periode pengamatan } \\
\mathrm{E}(\mathrm{Ri}) & =\text { expected return pada periode pengamatan }
\end{array}
$$


$\mathrm{N} \quad=$ periode pengamatan

Sehingga rumus yang digunakan untuk menghitung standar deviasi adalah sebagai berikut

$$
\sigma=\sqrt{\sigma \mathrm{i}^{2}}
$$

Keterangan:

$\sigma \quad=$ standar deviasi

$\sqrt{\sigma \mathrm{i}^{2}} \quad=$ akar dari varian

Menghitung risiko pasar berdasarkan beta $(\beta)$, hasil dari perhitungan beta digunakan untuk dimasukan dalam metode treynor.

$$
\beta_{i}=\frac{\sigma_{\mathrm{iM}}}{\sigma^{2} M}
$$

Keterangan:

$\beta_{\mathrm{i}} \quad=$ beta sekuritas ke-i

$\sigma_{\mathrm{iM}} \quad=$ kovarian return antara sekuritas ke-i dengan return pasar

$\sigma^{2} \mathrm{M} \quad=$ varian return pasar

Menghitung kinerja portofolio reksadana saham menggunakan metode sharpe. Hasil perhitungan metode sharpe digunakan untuk menilai kinerja portofolio dalam reksadanasaham.

$$
\operatorname{RVAR}=\frac{\overline{\mathbf{T R}_{\mathrm{p}}}-\overline{\mathrm{R}_{\mathrm{BR}}}}{\sigma_{\mathrm{p}}}
$$

Keterangan:

$\mathrm{RVAR}=$ reward to variability atau metode sharpe

$\overline{\mathrm{TR}_{\mathrm{p}}} \quad=$ rata-rata return total portofolio dalam periode tertetntu

$\overline{\mathrm{R}_{\mathrm{BR}}} \quad=$ rata-rata return aktiva bebas risiko dalam periode tertentu

$\sigma_{\mathrm{p}} \quad=$ variabilitas yang diukur dengan deviasi standar dari return portofolio dalam periode tertentu

$\overline{\mathrm{TR}_{\mathrm{p}}}-\overline{\mathrm{R}_{\mathrm{BR}}} \quad=$ return lebih (excess return) portofolio

Menghitung kinerja portofolio reksadana saham menggunakan metode treynor. Hasil perhitungan metode treynor digunakan untuk menilai kinerja portofolio dalam reksadana.

$$
\text { RVOL }=\frac{\overline{\mathbf{T R}_{\mathrm{P}}}-\overline{\mathbf{R}_{\mathrm{BR}}}}{\boldsymbol{\beta}_{\mathrm{P}}}
$$

Keterangan:

RVOL = reward to volatility atau metode treynor

$\overline{\mathrm{TR}_{\mathrm{p}}} \quad=$ rata-rata return total portofolio dalam periode tertetntu

$\overline{\mathrm{R}_{\mathrm{BR}}} \quad=$ rata-rata return aktiva bebas risiko dalam periode tertentu

$\beta_{\mathrm{p}} \quad=$ volatilitas yang diukur dengan beta portofolio periode tertentu

$\overline{\mathrm{TR}_{\mathrm{P}}}-\overline{\mathrm{R}_{\mathrm{BR}}} \quad=$ return lebih (excess return) portofolio

\section{HASIL DAN PEMBAHASAN \\ 4.1 Deskripsi Objek Penelitian}

Objek yang digunakan dalam penelitian ini adalah reksadana saham yang terdaftar di Bursa Efek Indonesia (BEI) dari tahun 2013-2016. Dipilihnya reksadana saham sebagai objek penelitian karena jenis reksadana saham memiliki return yang paling tinggi di antara jenis 
reksadana lainnya, hal ini dikarenakan sebesar $80 \%$ aktiva dalam reksadana ini berupa sahamsaham di Indonesia.

Berdasarkan proses seleksi sampel reksadana saham dengan kriteria yang telah ditetapkan di atas, terpilih 66 reksadana saham dari 210 saham, yang akan dijadikan sampel dengan periode pengamatan selama 4 tahun.

\subsection{Deskripsi Data Penelitian}

Data penelitian diambil berdasarkan laporan Nilai Aktiva Bersih (NAB) yang dipublikasikan pada website http://www.kontan.com untuk periode 2013-2014. Penelitian ini menggunakan metode sharpe dan metode treynor untuk menganalisis return dan risiko pada reksadana saham sehingga akan didapatkan hasil kinerja portofolio pada reksadana saham serta dibandingkan Indeks Harga Saham Gabungan (IHSG) sebagai kinerja pasar. Sumber: www.kontan.com.

Reksadana saham di atas terpilih menjadi sampel penelitian dari populasi yang ada berdasarkan kriteria yang telah ditetapkan dengan menggunakan metode purposive sampling.

\subsection{Analisis Data}

Dalam menghitung kinerja reksadana saham menggunakan metode sharpe dan metode treynor, maka langkah-langkah yang dilakukan adalah sebagai berikut.

a. Menentukan tingkat return dari masing-masing reksadana saham.

b. Menentukan tingkat return dari IHSG sebagai pembanding.

c. Menentukan nilai tingkat dari return bebas risiko (RBR).

d. Menentukan tingkat risiko dari masing-masing reksadana saham dan IHSG sebagai pembanding.

e. Menentukan tingkat risiko pasar menggunakan Beta.

f. Menentukan kinerja reksadana saham menggunakan metode sharpe.

g. Menentukan kinerja IHSG menggunakan metode sharpe.

h. Menentukan kinerja reksadana saham menggunakan metode treynor.

i. Menentukan kinerja IHSG menggunakan metode treynor.

\subsection{Menentukan Tingkat Return Dari Masing-Masing Reksadana Saham}

Return merupakan keuntungan yang diperoleh dari hasil investasi yang telah dilakukan investor. Pada reksadana, return yang dihasilkan dapat dilihat dari Nilai Aktiva Bersih (NAB) yaitu jumlah aset dalam reksadana yang telah dikurangi kewajiban-kewajiban yang ada. Untuk menentukan rata-rata return bulanan pada reksadana saham dengan menghitung return dari Nilai Aktiva Bersih (NAB) reksadana saham, maka rumus yang digunakan adalah sebagai berikut :

$$
\text { Return }=\frac{\mathbf{N A B}_{\mathrm{t}}-\mathbf{N A B} \mathbf{B}_{\mathrm{t}-1}}{\mathbf{N A B}_{\mathrm{t}-1}}
$$

Berdasarkan rumus di atas, maka perhitungan return reksadana saham Asanusa Blue Chip Value Fund 2 pada bulan Januari 2013 sebagai berikut ini.

$$
\text { Return }=\frac{1030.50-1008.80}{1008.80} \times 100=2.15 \%
$$

Berdasarkan perhitungan di atas, diketahui NAB Asanusa Blue Chip Value Fund 2 pada bulan Desember 2012 sebesar Rp1008.80,- dan NAB pada bulan Januari 2013 sebesar Rp1030.80,-. Sehingga return yang dihasilkan oleh Asanusa Blue Chip Value Fund 2 pada bulan Januari 2013 sebesar 2.15\%. Perhitungan return masing-masing reksadana saham pada bulan berikutnya menggunakan rumus yang sama. Setelah mendapatkan return perbulan 
pada reksadana saham, maka selanjutnya adalah menentukan rata-rata return bulanan dengan bantuan rumus Microsoft Excel yaitu =AVERAGE(..). Sehingga hasil rata-rata return bulanan yang dihasilkan reksadana saham Asanusa Blue Chip Value Fund 2 pada tahun 2013 adalah sebesar $0.12 \%$. Perhitungan return masing-masing reksadana saham pada bulan berikutnya menggunakan rumus yang sama.

\subsection{Menentukan Tingkat Return Dari IHSG Sebagai Pembanding}

Indeks Harga Saham Gabungan (IHSG) merupakan indeks yang menggunakan semua harga saham yang tercatat dalam Bursa Efek Indonesia (BEI) sebagai komponen perhitungan. Return bulanan IHSG sebagai pembanding dengan reksadana saham didapatkan dari data close price bulanan IHSG. Perhitungan yang dilakukan sama dengan cara menghitung return bulanan pada reksadana saham. Rumus yang digunakan untuk menghitung return IHSG adalah sebagai berikut.

$$
=\frac{\text { IHSG }_{\mathbf{t}}-\text { IHSG }_{\mathbf{t}-1}}{\text { IHSG }_{\mathbf{t}-1}}
$$

Berdasarkan rumus di atas, maka perhitungan return IHSG pada bulan Januari 2013 sebagai berikut ini.

$$
R_{M}=\frac{4,453.70-4,316.69}{4,316.69} \times 100=3.17 \%
$$

Berdasarkan perhitungan di atas, diketahui close price IHSG pada bulan Desember 2012 sebesar Rp4,316.69,- dan close price IHSG pada bulan Januari 2013 sebesar Rp4,453.70. Sehingga return yang dihasilkan oleh IHSG pada bulan Januari 2013 sebesar 3.17\%. Perhitungan return IHSG pada bulan berikutnya menggunakan rumus yang sama. Setelah mendapatkan return perbulan pada IHSG, maka selanjutnya adalah menentukan rata-rata return bulanan dengan bantuan rumus Microsoft Excel yaitu=AVERAGE(..). Sehingga hasil rata-rata return bulanan yang dihasilkan IHSG pada tahun 2013 adalah sebesar $0.03 \%$. Perhitungan return IHSG pada bulan berikutnya menggunakan rumus yang sama.

\subsection{Menentukan Nilai Tingkat Dari Return Bebas Risiko (RBR)}

Suku bunga Bank Indonesia (SBI) digunakan untuk mendapatkan nilai return bebas risiko. Return bebas risiko merupakan imbal hasil yang pasti akan diterima investor di masa yang akan datang, dimana tidak ada risiko yang ditanggung oleh investor. Data SBI didapatkan dari website http://www.bi.go.id yang merupakan situs resmi Bank Indonesia. Rumus yang digunakan untuk menghitung BI Rate adalah sebagai berikut.

\section{$\mathrm{RBR}=\frac{\sum \mathrm{BI} \text { Rate }}{\mathbf{n}}$}

Berdasarkan rumus di atas, maka perhitungan RBR dapat dilihat pada tabel dibawah ini

Tabel 2.

SUKU BUNGA BANK INDONESIA BI RATE (\%)

\begin{tabular}{|l|c|c|c|c|c|c|}
\hline \multirow{3}{*}{ Bulan } & \multirow{5}{*}{$\mathbf{2 0 1 3}$} & $\mathbf{2 0 1 4}$ & $\mathbf{2 0 1 5}$ & & \multicolumn{3}{c|}{$\begin{array}{c}\text { BI 7 Day Repo } \\
\text { Rate }\end{array}$} \\
\cline { 4 - 8 } & & & & & & 7.25 \\
\hline Januari & 5.75 & 7.50 & 7.75 & 7.25 & & 7.00 \\
\hline Februari & 5.75 & 7.50 & 7.50 & 7.00 & & 6.75 \\
\hline Maret & 5.75 & 7.50 & 7.50 & 6.75 & & 6.13 \\
\hline April & 5.75 & 7.50 & 7.50 & 6.75 & 5.50 & 6.13 \\
\hline Mei & 5.75 & 7.50 & 7.50 & 6.75 & 5.50 & \\
\hline
\end{tabular}




\begin{tabular}{|l|c|c|c|c|c|c|}
\hline Juni & 6.00 & 7.50 & 7.50 & 6.50 & 5.25 & 5.88 \\
\hline Juli & 6.50 & 7.50 & 7.50 & 6.50 & 5.25 & 5.88 \\
\hline Agustus & 6.75 & 7.50 & 7.50 & & 5.25 & 5.25 \\
\hline September & 7.25 & 7.50 & 7.50 & & 5.00 & 5.00 \\
\hline Oktober & 7.25 & 7.50 & 7.50 & & 4.75 & 4.75 \\
\hline November & 7.50 & 7.63 & 7.50 & & 4.75 & 4.75 \\
\hline Desember & 7.50 & 7.75 & 7.50 & & 4.75 & 4.75 \\
\hline RBR & $\mathbf{0 . 5 4}$ & $\mathbf{0 . 6 3}$ & $\mathbf{0 . 6 3}$ & & & $\mathbf{0 . 4 8}$ \\
\hline \multicolumn{7}{|c|}{ Sumber: www.bi.go.id (data di olah) } \\
\end{tabular}

Berdasarkan tabel di atas, contoh jika rata-rata return bulanan BI rate pada tahun 2013 sebesar $0.54 \%$, maka hal ini menjelaskan bahwa jika investor melakukan investasi pada SBI maka akan memperoleh return sebesar $0.54 \%$ perbulan. Return tersebut pasti akan diterima oleh investor karena SBI adalah investasi yang tidak mengandung risiko.

\subsection{Menentukan Tingkat Risiko Dari Masing-Masing Reksadana Saham Dan IHSG Sebagai Pembanding}

Dalam menentukan tingkat risiko total dari reksadana saham dan IHSG, rumus pertama yang digunakan adalah rumus standar deviasi untuk mengukur risiko total dari investasi tersebut. Pada penelitian ini menghitung standar deviasi menggunakan Microsoft Excel yaitu $=\operatorname{STDEV}(.$.$) , dan rumus yang digunakan adalah sebagai berikut.$

$$
\sigma i^{2}=\frac{\sum_{j=1}^{\mathrm{n}}\left\{\mathbf{R}_{\mathrm{ij}}-\mathbf{E}\left(\mathrm{R}_{\mathrm{i}}\right)\right\}^{2}}{\mathbf{N}}
$$

Sehingga rumus yang digunakan untuk menghitung standar deviasi adalah sebagai berikut:

$$
\sigma=\sqrt{\sigma i^{2}}
$$

Berdasarkan rumus di atas, maka perhitungan standar deviasi untuk reksadana saham Asanusa Blue Chip Value Fund 2 pada tahun 2013 adalah sebagai berikut :

$$
\sigma=\sqrt{15.84 \%}=3.98 \%
$$

Berdasarkan perhitungan di atas, pada rata-rata return yang dihasilkan reksadana saham Asanusa Blue Chip Value Fund 2 sebesar $0.12 \%$ pada tahun 2013 terdapat tingkat risiko total yang dihadapi perusahaan sebesar $3.98 \%$. Perhitungan tingkat risiko dengan menggunakan standar deviasi pada reksadana saham lainnya menggunakan rumus yang sama. Untuk menentukan tingkat risiko pada IHSG tahun 2013 menggunakan rumus standar deviasi yang sama seperti di atas, maka perhitungan risikonya adalah sebagai berikut.

$$
\sigma=\sqrt{24.30 \%}=4.93 \%
$$

Berdasarkan perhitungan di atas, Berdasarkan perhitungan di atas, pada return yang dihasilkan IHSG sebesar $0.03 \%$ pada tahun 2013 terdapat tingkat risiko total yang dihadapi pasar yaitu sebesar $4.93 \% \%$. Perhitungan tingkat risiko dengan menggunakan standar deviasi pada IHSG menggunakan rumus yang sama. 


\subsection{Menentukan Tingkat Risiko Pasar Menggunakan Beta}

Untuk menentukan tingkat risiko pasar dari masing-masing reksadana saham menggunakan beta, pertama menghitung kovarian yaitu perbandingan return perusahaan dengan return pasar, menghitung kovarian menggunakan bantuan rumus excel yaitu $=\operatorname{COVAR}(.$.$) . Dan$ varian pasar merupakan besaran risiko yang dihadapi oleh pasar, menghitung varian menggunakan bantuan rumus excel yaitu $=\operatorname{VAR}(.$.$) . Maka rumus yang digunakan mencari$ beta adalah sebagai berikut.

$$
\beta_{i}=\frac{\sigma_{i M}}{\sigma^{2} M}
$$

Berdasarkan rumus di atas, maka perhitungan beta pada reksadana saham Asanusa Blue Chip Value Fund 2 pada tahun 2013 adalah sebagai berikut.

$$
\beta_{\mathrm{i}}=\frac{13.86 \%}{24.27 \%}=0.57 \%
$$

Hasil perhitungan di atas, menunjukkan return yang dihasilkan reksadana saham Asanusa Blue Chip Value Fund 2 sebesar $0.12 \%$ pada tahun 2013 terdapat tingkat risiko pasar yang dihadapi perusahaan sebesar $0.57 \%$. Perhitungan tingkat risiko dengan menggunakan beta pada reksadana saham lainnya menggunakan rumus yang sama.

\subsection{Menentukan Kinerja Reksadana Saham Menggunakan Metode Sharpe}

Untuk menentukan kinerja reksadana saham menggunakan metode sharpe, maka rumus yang digunakan dalam perhitungannya adalah sebagai berikut.

$$
\text { RVAR }=\frac{\overline{T_{p}}-\overline{R_{B R}}}{\sigma_{p}}
$$

Maka perhitungan kinerja portofolio pada reksadana saham Asanusa Blue Chip Value Fund 2 pada tahun 2013 adalah.

$$
\text { RVAR }=\frac{0.12 \%-0.54 \%}{4.93 \%}=-0.10 \%
$$

Perhitungan di atas menghasilkan kinerja reksadana saham Asanusa Blue Chip Value Fund 2 yang dihasilkan dengan menggunakan metode sharpe pada tahun 2013 adalah sebesar $0.10 \%$. Hal ini menjelaskan bahwa kinerja reksadana saham Asanusa Blue Chip Value Fund 2 memiliki kinerja yang negative, karena excess return lebih kecil dibandingkan dengan risiko total yang dihadapi..

Secara teori, semakin besar hasil kinerja portofolio dari reksadana saham maka akan semakin baik kinerjanya karena return yang dihasilkan lebih besar dari risiko yang dihadapi pada investasinya. Perhitungan kinerja portofolio pada reksadana saham dengan menggunakan menggunakan metode sharpe dihitung dengan rumus yang sama.

\subsection{Menentukan Kinerja IHSG Menggunakan Metode Sharpe}

Menentukan kinerja IHSG sebagai pembanding menggunakan metode sharpe dilakukan untuk membandingkan apakah kinerja reksadana saham berada di atas atau di bawah kinerja IHSG yang mencakup keseluruhan saham di Indonesia. Perhitungan kinerja IHSG dengan metode sharpe menggunakan rumus yang sama pada perhitungan kinerja reksadana saham. Berikut ini adalah perhitungan kinerja IHSG tahun 2013 menggunakan metode sharpe. 


$$
\text { RVAR }=\frac{0.03 \%-0.54 \%}{4.93 \%}=-0.10 \%
$$

Berdasarkan perhitungan di atas, hasil dari kinerja IHSG menggunakan metode sharpe adalah sebesar $-0.10 \%$. Hal ini menjelaskan bahwa kinerja pasar menghasilkan kinerja negatif pada tahun 2013. Hasil perhitungan kinerja IHSG sama dengan hasil perhitungan kinerja reksadana saham Asanusa Blue Chip Value Fund 2, yang berarti kinerja reksadana saham tersebut searah dengan kinerja pasar. Perbandingan hasil kinerja portofolio pada reksadana saham dengan kinerja IHSG menggunakan metode sharpe dihitung dengan rumus yang sama.

\subsection{Menentukan Kinerja Reksadana Saham Menggunakan Metode Treynor}

Metode treynor merupakan perhitungan kinerja portofolio yang membandingkan excess return dengan risiko pasar yang dihitung dengan beta. Untuk menentukan kinerja reksadana saham menggunakan metode treynor, maka rumus yang digunakan dalam perhitungannya adalah sebagai berikut.

$$
\text { RVOL }=\frac{\overline{\mathbf{T R}_{\mathrm{P}}}-\overline{\mathbf{R}_{\mathrm{BR}}}}{\boldsymbol{\beta}_{\mathrm{P}}}
$$

Maka perhitungan kinerja portofolio pada reksadana saham Asanusa Blue Chip Value Fund 2 pada tahun 2013 adalah sebagai berikut.

$$
\text { RVOL }=\frac{0.12 \%-0.54 \%}{0.57 \% \%}=-0.73 \%
$$

Berdasarkan hasil perhitungan di atas, kinerja reksadana saham Asanusa Blue Chip Value Fund 2 yang dihasilkan dengan menggunakan metode treynor pada tahun 2013 adalah sebesar $-0.73 \%$. Hal ini menjelaskan bahwa kinerja reksadana saham Asanusa Blue Chip Value Fund 2 memiliki kinerja yang negatif karena excess return lebih kecil daripada risiko pasar yang dihadapi..

Secara teori, semakin besar hasil kinerja portofolio dari reksadana saham maka akan semakin baik kinerjanya karena return yang dihasilkan lebih besar dari risiko yang dihadapi pada investasinya. Perhitungan kinerja portofolio pada reksadana saham dengan menggunakan metode treynor dihitung dengan rumus yang sama.

\subsection{Menentukan Kinerja IHSG Menggunakan Metode Treynor}

Menentukan kinerja IHSG sebagai pembanding menggunakan metode treynor dilakukan untuk membandingkan apakah kinerja reksadana saham berada di atas atau di bawah kinerja IHSG yang mencakup keseluruhan saham di Indonesia. Perhitungan kinerja IHSG dengan metode treynor menggunakan rumus yang sama pada perhitungan kinerja reksadana saham. Berikut ini adalah perhitungan kinerja IHSG tahun 2013 menggunakan metode treynor.

$$
\text { RVAR }=\frac{0.03 \%-0.54 \%}{0.92 \%}=-0.55 \%
$$

Berdasarkan perhitungan di atas, hasil dari kinerja IHSG menggunakan metode treynor adalah sebesar $-0.57 \%$. Hal ini menjelaskan bahwa kinerja pasar menghasilkan kinerja negatif pada tahun 2013. Hasil perhitungan kinerja IHSG berbeda dengan hasil perhitungan kinerja reksadana saham Asanusa Blue Chip Value Fund 2 sebesar $-0.73 \%$, yang menjelaskan bahwa kinerja reksadana saham Asanusa Blue Chip Value Fund 2 masih berada dibawah kinerja pasar. Perbandingan hasil kinerja portofolio pada reksadana saham dengan kinerja IHSG menggunakan metode treynor dihitung dengan rumus yang sama. 


\subsection{Kinerja Reksadana Saham Menggunakan Metode Sharpe Tahun 2013}

Hasil perhitungan kinerja portofolio pada reksadana saham menggunakan metode sharpe tahun 2013 sebanyak 10 reksadana saham memiliki kinerja positif, sedangkan 56 reksadana saham memiliki kinerja negatif. Secara teori, semakin besar hasil kinerja portofolio menggunakan metode sharpe, maka kinerjanya semakin baik karena return yang dihasilkan lebih besar dibandingkan dengan dengan risikonya. Hal ini menunjukkan bahwa sebanyak 10 reksadana saham dapat menjadi pilihan investasi. Berikut ini merupakan daftar 10 kinerja reksadana saham terbaik menggunakan metode sharpe tahun 2013.

Tabel 3.

Kinerja Reksadana Saham Terbaik

Menggunakan Metode Sharpe Tahun 2013

\begin{tabular}{rlc}
\hline No & \multicolumn{1}{c}{ Reksadana Saham } & $\begin{array}{c}\text { Metode } \\
\text { Sharpe }(\%)\end{array}$ \\
\hline 1 & Prospera Bijak & 0.66 \\
\hline 2 & Millenium Equity & 0.59 \\
\hline 3 & Grow-2-Prosper & 0.18 \\
\hline 4 & Dana Pratama Ekuitas & 0.10 \\
\hline 5 & Sam Indonesian Equity Fund & 0.09 \\
\hline 6 & First State Indoequity High Conviction Fund & 0.07 \\
\hline 7 & HPAM Ultima Ekuitas 1 & 0.04 \\
\hline 8 & Archipelago Equity Growth & 0.02 \\
\hline 9 & Rhb Alpha Sector Rotation & 0.01 \\
\hline 10 & Batavia Dana Saham Optimal & 0.00 \\
\hline
\end{tabular}

Sumber: Data di olah

Berdasarkan tabel di atas, kinerja reksadana saham terbaik menggunakan metode sharpe adalah reksadana saham Prospera Bijak dengan nilai kinerja sebesar $0.66 \%$, sedangkan yang kedua reksadana saham Millenium Equity dengan nilai kinerja sebesar $0.59 \%$, dan peringkat ketiga adalah reksadana saham Grow-2-Prosper dengan nilai kinerja sebesar $0.18 \%$.

\subsection{Kinerja Reksadana Saham Menggunakan Metode Sharpe Tahun 2014}

Hasil perhitungan kinerja portofolio pada reksadana saham menggunakan metode sharpe tahun 2014 sebanyak 64 reksadana saham memiliki kinerja positif, sedangkan 2 reksadana saham memiliki kinerja negatif. Hal ini menunjukkan bahwa sebanyak 64 reksadana saham dapat menjadi pilihan investasi, semakin besar hasil kinerja portofolio menggunakan metode sharpe, maka kinerjanya semakin baik karena return yang dihasilkan lebih besar dibandingkan dengan dengan risikonya. Berikut ini merupakan daftar 3 peringkat kinerja reksadana saham terbaik menggunakan metode sharpe tahun 2014.

Tabel 4.

Kinerja Reksadana Saham Terbaik Menggunakan Metode Sharpe Tahun 2014

\begin{tabular}{clc}
\hline No & \multicolumn{1}{|c}{ Reksadana Saham } & $\begin{array}{c}\text { Metode Sharpe } \\
(\%)\end{array}$ \\
\hline 1 & Simas Saham Unggulan & 0.87 \\
\hline 2 & BNP Paribas Infrastruktur Plus & 0.78 \\
\hline 3 & Dana Pratama Ekuitas & 0.76 \\
\hline
\end{tabular}

Sumber: Data di olah 


\subsection{Kinerja Reksadana Saham Menggunakan Metode Sharpe Tahun 2015}

Hasil perhitungan kinerja portofolio pada reksadana saham menggunakan metode sharpe tahun 2015 tidak menghasilkan kinerja reksadana yang positif, karena keseluruhan kinerja reksadana negatif. Hal ini menunjukkan bahwa pada tahun 2015 reksadana saham belum dapat dijadikan pilihan investasi, karena return yang dihasilkan lebih kecil daripada risiko yang dihadapi. Karena tidak sesuai dengan teori, dimana semakin besar hasil kinerja portofolio menggunakan metode sharpe, maka kinerjanya semakin baik karena return yang dihasilkan lebih besar dibandingkan dengan dengan risikonya. Berikut ini kinerja reksadana saham yang mengalami penurunan paling rendah menggunakan metode sharpe tahun 2015 adalah sebagai berikut.

Tabel 5.

Kinerja Reksadana Saham Yang Mengalami Penurunan Menggunakan Metode Sharpe Tahun 2015

\begin{tabular}{clc}
\hline No & \multicolumn{1}{|c}{ Reksadana Saham } & $\begin{array}{c}\text { Metode Sharpe } \\
(\%)\end{array}$ \\
\hline 1 & Syailendra Equity Alpha Fund & -0.46 \\
\hline 2 & PNM Saham Agresif & -1.13 \\
\hline 3 & Dana Pratama Ekuitas & -1.19 \\
\hline Sumber: Data di olah
\end{tabular}

\subsection{Kinerja Reksadana Saham Menggunakan Metode Sharpe Tahun 2016}

Hasil perhitungan kinerja portofolio pada reksadana saham menggunakan metode sharpe tahun 2016 sebanyak 59 reksadana saham memiliki kinerja positif, sedangkan 7 reksadana saham memiliki kinerja negatif. Hal ini menunjukkan bahwa sebanyak 59 reksadana saham dapat menjadi pilihan investasi pada tahun 2016, semakin besar hasil kinerja portofolio menggunakan metode sharpe, maka kinerjanya semakin baik karena return yang dihasilkan lebih besar dibandingkan dengan dengan risikonya. Berikut ini merupakan perusahaan dengan kinerja reksadana saham terbaik menggunakan metode sharpe tahun 2016.

Tabel 6.

Kinerja Reksadana Saham Terbaik

Menggunakan Metode Sharpe Tahun 2016

\begin{tabular}{|c|c|c|}
\hline No & Reksadana Saham & $\begin{array}{c}\text { Metode } \\
\text { Sharpe }(\%)\end{array}$ \\
\hline 1 & Sam Indonesian Equity Fund & $0.61 \%$ \\
\hline 2 & Asanusa Blue Chip Value Fund 2 & $0.58 \%$ \\
\hline
\end{tabular}

Sumber: Data di olah

\subsection{Kinerja Reksadana Saham Menggunakan Metode Treynor Kinerja Reksadana Saham Menggunakan Metode Treynor Tahun 2013}

Hasil perhitungan kinerja portofolio pada reksadana saham menggunakan metode treynor tahun 2013 sebanyak 56 reksadana saham memiliki kinerja negatif, sedangkan 10 reksadana saham memiliki kinerja positif. Hal ini menunjukkan bahwa sebanyak 10 reksadana saham dapat menjadi pilihan investasi pada tahun 2013, semakin besar hasil kinerja portofolio menggunakan metode treynor, maka kinerjanya semakin baik karena return yang dihasilkan lebih besar dibandingkan dengan dengan risiko pasar yang dihadapi perusahaan. Berikut ini merupakan 2 perusahaan dengan kinerja reksadana saham terbaik menggunakan metode treynor tahun 2013. 
Tabel 7.

Kinerja Reksadana Saham Terbaik

Menggunakan Metode Treynor Tahun 2013

\begin{tabular}{clc}
\hline \multirow{2}{*}{ No } & \multicolumn{1}{c}{ Reksadana Saham } & $\begin{array}{c}\text { Metode Treynor } \\
(\%)\end{array}$ \\
\hline 1 & Prospera Bijak & 40.24 \\
\hline 2 & Millenium Equity & 3.81 \\
\hline
\end{tabular}

Sumber: Data di olah

\section{Kinerja Reksadana Saham Menggunakan Metode Treynor Tahun 2014}

Hasil perhitungan kinerja portofolio pada reksadana saham menggunakan metode treynor tahun 2014 sebanyak 65 reksadana saham memiliki kinerja positif, sedangkan 1 reksadana saham memiliki kinerja negatif. Hal ini menunjukkan bahwa sebanyak 65 reksadana saham dapat menjadi pilihan investasi pada tahun 2014, semakin besar hasil kinerja portofolio menggunakan metode treynor, maka kinerjanya semakin baik karena return yang dihasilkan lebih besar dibandingkan dengan dengan risiko pasar yang dihadapi perusahaan. Berikut ini merupakan daftar 65 kinerja reksadana saham terbaik menggunakan metode treynor tahun 2014.

Tabel 8

Kinerja Reksadana Saham Terbaik Menggunakan Metode Treynor Tahun 2014

\begin{tabular}{clc}
\hline No & Reksadana Saham & $\begin{array}{c}\text { Metode } \\
\text { Treynor } \\
(\%)\end{array}$ \\
\hline 1 & Simas Saham Unggulan & 4.17 \\
\hline 2 & Mandiri Dynamic Equity & 2.32 \\
\hline Sumber: Data di olah
\end{tabular}

\section{Kinerja Reksadana Saham Menggunakan Metode Treynor Tahun 2015}

Hasil perhitungan kinerja portofolio pada reksadana saham menggunakan metode treynor tahun 2015 tidak menghasilkan kinerja reksadana yang positif, karena keseluruhan kinerja reksadana negatif. Hal ini menunjukkan bahwa pada tahun 2015 reksadana saham belum dapat dijadikan investasi, karena return yang dihasilkan lebih kecil daripada risiko yang dihadapi. Karena tidak sesuai dengan teori, dimana semakin besar hasil kinerja portofolio menggunakan metode treynor, maka kinerjanya semakin baik karena return yang dihasilkan lebih besar dibandingkan dengan dengan risiko pasar yang dihadapi perusahaan. Berikut ini kinerja reksadana saham yang mengalami penurunan paling rendah menggunakan metode treynor tahun 2015 adalah sebagai berikut.

Tabel 92

Kinerja Reksadana Saham Yang Mengalami Penurunan Menggunakan Metode Treynor Tahun 2015

\begin{tabular}{clc}
\hline No & \multicolumn{1}{c}{ Reksadana Saham } & $\begin{array}{c}\text { Metode } \\
\text { Treynor }(\%)\end{array}$ \\
\hline 1 & Schroder Dana Prestasi Plus & -1.01 \\
\hline 2 & Syailendra Equity Alpha Fund & -1.11 \\
\hline
\end{tabular}

Sumber: Data di olah

Kinerja Reksadana Saham Menggunakan Metode Treynor Tahun 2016

Hasil perhitungan kinerja portofolio pada reksadana saham menggunakan metode treynor tahun 2016 sebanyak 59 reksadana saham memiliki kinerja positif, sedangkan 7 reksadana 
saham memiliki kinerja negatif. Hal ini menunjukkan bahwa sebanyak 58 reksadana saham dapat menjadi pilihan investasi pada tahun 2016, semakin besar hasil kinerja portofolio menggunakan metode treynor, maka kinerjanya semakin baik karena return yang dihasilkan lebih besar dibandingkan dengan dengan risiko pasar yang dihadapi perusahaan. Berikut adalah 2 perusahaan dengan kinerja terbaik menurut metode treynor.

Tabel 30

Kinerja Reksadana Saham Terbaik

Menggunakan Metode Treynor Tahun 2016

\begin{tabular}{clc}
\hline No & \multicolumn{1}{c}{ Reksadana Saham } & $\begin{array}{c}\text { Metode } \\
\text { Treynor }(\%)\end{array}$ \\
\hline 1 & Schroder 90 Plus Equity Fund & 16.48 \\
\hline 2 & Asanusa Blue Chip Value Fund 2 & 3.94 \\
\hline
\end{tabular}

\section{Perbandingan Kinerja Reksadana Saham Menggunakan Metode Sharpe Dan Metode Treynor}

Berdasarkan hasil perhitungan kinerja reksadana saham menggunakan metode sharpe dan metode treynor memiliki hasil yang berbeda. Pada tahun 2013 rata-rata kinerja reksadana saham menggunakan metode treynor sebesar $-0.11 \%$ berada di atas rata-rata hasil perhitungan metode sharpe sebesar -0.21. Namun pada tahun 2016 rata-rata kinerja reksadana saham menggunakan metode treynor sebesar $0.12 \%$ berada di bawah rata-rata hasil perhitungan metode sharpe sebesar $0.13 \%$.

Pada tahun 2013 dan tahun 2015 rata-rata hasil kinerja reksadana saham menggunakan metode sharpe berada di bawah rata-rata kinerja metode treynor. Ini berarti portofolio dalam reksadana saham tersebut belum terdiversifikasi dengan baik karena dalam metode sharpe membandingkan return dengan risiko total (standar deviasi) yang dihadapi investor. Sedangkan pada tahun 2014 dan tahun 2016 rata-rata kinerja reksadana saham menggunakan metode treynor berada di atas metode sharpe, yang berarti bahwa portofolio dalam reksadana saham tersebut sudah terdiversifikasi dengan baik sehingga risiko yang dihadapi hanya risiko pasar atas return yang diterima oleh investor.

Dalam menentukan metode yang lebih baik di antara metode sharpe dan metode treynor dapat dilihat dari portofolio masing-masing dalam reksadana saham tersebut. Jika reksadana saham sudah terdiversifikasi dengan baik maka risiko yang pasti terjadi adalah risiko pasar, oleh karena itu menghitung kinerja portofolionya dengan metode treynor. Namun jika portofolio dalam reksadana saham hanya sedikit dipengaruhi oleh risiko pasar maka lebih baik menghitung kinerjanya menggunakan metode sharpe.

Perbandingan Kinerja Reksadana Saham Dengan Kinerja IHSG Menggunakan Metode Sharpe

Table 11

Perbandingan Kinerja Reksadana Saham Dengan Kinerja IHSG Menggunakan Metode Sharpe

\begin{tabular}{ccc}
\hline Tahun & Di Atas Pasar & Dibawah Pasar \\
\hline 2013 & 22 Reksadana Saham & 44 Reksadana Saham \\
\hline 2014 & 18 Reksadana Saham & 48 Reksadana Saham \\
\hline 2015 & 25 Reksadana Saham & 41 Reksadana Saham \\
\hline 2016 & 4 Reksadana Saham & 62 Reksadana Saham \\
\hline
\end{tabular}

Sumber: Data di olah

Berdasarkan tabel di atas, kinerja reksadana saham yang berada di atas pasar paling banyak berada pada tahun 2015 sebanyak 25 reksadana saham, sedangkan hasil kinerja reksadana saham yang sangat sedikit berada di atas pasar pada tahun 2016 hanya sebanyak 4 reksadana saham. Dari tahun 2013-2016, jumlah kinerja reksadana saham yang di bawah 
pasar lebih banyak dairpada yang berada di atas pasar, hal ini berarti bahwa setiap pergerakan saham di dalam pasar, sangat mempengaruhi portofolio saham yang ada pada reksadana saham. Artinya return tinggi yang dihasilkan pada investasi reksadana saham belum dapat dinilai kinerja portofolionya, sehingga harus disesuaikan dengan risiko yang dihadapi oleh investor.

\section{Perbandingan Kinerja Reksadana Saham Dengan Kinerja IHSG Menggunakan Metode Treynor}

Tabel 12

Perbandingan Kinerja Reksadana Saham Dengan Kinerja IHSG Menggunakan Metode Treynor

\begin{tabular}{ccc} 
Tahun & Di Atas Pasar & Dibawah Pasar \\
\hline 2013 & 20 Reksadana Saham & 46 Reksadana Saham \\
\hline 2014 & 28 Reksadana Saham & 38 Reksadana Saham \\
\hline 2015 & 9 Reksadana Saham & 57 Reksadana Saham \\
\hline 2016 & 14 Reksadana Saham & 52 Reksadana Saham
\end{tabular}

Sumber: Data di olah

Berdasarkan tabel di atas, kinerja reksadana saham yang berada di atas pasar paling banyak berada pada tahun 2014 sebanyak 28 reksadana saham, sedangkan hasil kinerja reksadana saham yang sangat sedikit berada di atas pasar pada tahun 2015 hanya sebanyak 9 reksadana saham. Dari tahun 2013-2016, jumlah kinerja reksadana saham yang di bawah pasar lebih banyak dairpada yang berada di atas pasar, hal ini berarti bahwa setiap pergerakan saham di dalam pasar, sangat mempengaruhi portofolio saham yang ada pada reksadana saham. Artinya return tinggi yang dihasilkan pada investasi reksadana saham belum dapat dinilai kinerja portofolionya, sehingga harus disesuaikan dengan risiko yang dihadapi oleh investor.

\section{Kinerja Reksadana Saham Yang Konsisten Selama Tahun 2013-2016}

Berdasarkan hasil perhitungan kinerja reksadana menggunakan metode sharpe dan metode treynor pada lampiran 2-9, kinerja reksadana saham menghasilkan perhitungan yang berbeda-beda. Berikut ini adalah beberapa hasil perhitungan kinerja reksadana saham menggunakan metode sharpe dan metode treynor.

Table 134

Beberapa Hasil Perhitungan Kinerja Reksadana Saham Menggunakan Metode Sharpe Dan Metode Treynor

\begin{tabular}{lcccccccc}
\hline \multirow{2}{*}{ Reksadana Saham } & \multicolumn{4}{c}{ Metode Sharpe } & \multicolumn{4}{c}{ Metode Treynor } \\
\cline { 2 - 9 } & 2013 & 2014 & 2015 & 2016 & 2013 & 2014 & 2015 & 2016 \\
\hline IHSG & -0.10 & 0.60 & -1.87 & 0.26 & -0.55 & 1.18 & -1.75 & 0.81 \\
\hline Dana Pratama Ekuitas & 0.10 & 0.76 & -1.19 & 0.05 & 0.58 & 1.67 & -1.13 & 0.16 \\
\hline Prospera Bijak & 0.66 & 0.63 & -1.56 & 0.13 & 40.24 & 1.39 & -1.73 & 0.47 \\
\hline Rhb Alpha Sector Rotation & 0.01 & 0.69 & -1.83 & 0.12 & 0.07 & 1.48 & -1.99 & 0.42 \\
\hline Sam Indonesian Equity Fund & 0.09 & 0.63 & -1.48 & 0.61 & 0.61 & 1.38 & -2.93 & 4.78 \\
\hline Schroder 90 Plus Equity Fund & -0.08 & 0.49 & -1.49 & 0.12 & -0.50 & 1.04 & -1.19 & 16.48 \\
\hline Schroder Dana Istimewa & -0.07 & 0.49 & -1.61 & 0.08 & -0.43 & 1.07 & -1.58 & 0.28 \\
\hline Schroder Dana Prestasi & -0.05 & 0.34 & -1.58 & 0.15 & -0.35 & 1.33 & -1.25 & 0.49 \\
\hline
\end{tabular}

Sumber: Data di olah

Berdasarkan tabel di atas, menjelaskan bahwa hasil perhitungan kinerja reksadana saham menunjukkan perbedaan menggunakan kedua metode tersebut. Namun hanya satu reksadana saham yang memiliki kinerja konsisten menggunakan metode sharpe yaitu reksadana Sam Indonesian Equity Fund, dimana hasil kinerja dari reksadana saham tersebut berada diatas kinerja pasar dari tahun 2013-2016. 


\section{SIMPULAN, KETERBATASAN DAN KONTRIBUSI PRAKTIS 5.1 Simpulan}

Berdasarkan analisis dan pembahasan kinerja portofolio pada reksadana saham yang terdaftar Bursa Efek Indonesia periode 2013-2016, maka dapat disimpulkan sebagai berikut.

a. Hasil perhitungan menunjukkan terdapat perbedaan hasil dari kinerja reksadana saham menggunakan metode sharpe dan metode treynor pada reksadana saham yang terdaftar pada Bursa Efek Indonesia (BEI) dimana masing-masing nilai kinerja berfluktuasi pada periode 2013-2016.

b. Hasil penelitian menunjukkan bahwa hanya beberapa reksadana saham yang berada di atas kinerja pasar dengan menggunakan metode sharpe yaitu pada tahun 2013 sebanyak 22 Reksadana Saham, tahun 2014 sebanyak 18 Reksadana Saham, tahun 2015 sebanyak 25 Reksadana Saham, dan tahun 20164 Reksadana Saham. Sedangkan kinerja yang berada di atas pasar menggunakan metode treynor pada tahun 2013 sebanyak 20 Reksadana Saham, tahun 2014 sebanyak 28 Reksadana Saham, tahun 2015 sebanyak 9 Reksadana Saham, dan pada tahun 2016 sebanyak 14 Reksadana Saham.

c. Hasil penelitian menunjukkan bahwa tidak terdapat kinerja reksadana saham yang konsisten berada di atas kinerja pasar menggunakan metode sharpe dan metode treynor pada periode 2013-2016. Hanya satu reksadana saham yang memiliki kinerja konsisten di atas kinerja pasar selama periode 2013-2016 menggunakan metode sharpe yaitu reksadana saham Sam Indonesian Equity Fund.

\subsection{Keterbatasan}

Secara garis besar keterbatasan penelitian ini adalah waktu yang tersedia untuk mengerjakan penelitian ini relatif sedikit yaitu kurang dari 6 bulan serta biaya yang disediakan sangat terbatas.

\section{Konstribusi Praktis}

a. Bagi Akademisi

Untuk penelitian selanjutnya, sebaiknya menambahkan metode kinerja portofolio lainnya seperti metode M2 dan information ratio, sehingga dapat dibandingkan dengan penelitian yang ada. Penelitian selanjutnya dapat menambah pembanding selain IHSG, yaitu LQ45 atau saham JII untuk mendapatkan kesimpulan yang berbeda.

b. Bagi Manajer Investasi dan investor

Diharapkan dapat mengevaluasi investasi dalam portofolio pada reksadana saham, agar portofolio reksadana saham terbentuk dengan baik sehingga dapat menjadi pilihan investasi bagi investor.

Hasil penelitian ini diharapkan dapat dijadikan referensi bagi investor dalam menentukan pilihan investasi reksadana saham yang memiliki kinerja terbaik.

\section{DAFTAR PUSTAKA}

Grafik Perbandingan Kinerja Reksadana Saham Dengan Kinerja IHSG. (2016). From Bareksa: http://www.bareksa.com/id/text/2016/07/19/kinerja-reksa-dana-saham-tertinggal-ihsg5-tahun-terakhir-apa-penyebabnya/13636/news

Kinerja Reksadana Saham Terbaik Sepanjang Tahun 2016. (2017). From kompas: http://bisniskeuangan.kompas.com/read/2017/01/06/090000226/ini.jajaran.reksa.dana.p aling.kinclong.sepanjang.2016

Bodie, Kane, \& Marcus. (2014). Manajemen Portofolio Dan Investigasi, Edisi Kesembilan, Jakarta: Salemba Empat. 
Darmadji, T., \& Fakhruddin, H. M. (2012). Pasar Modal Di Indonesia Pendekatan Tanya Jawab, Edisi Ketiga, Jakarta: Salemba Empat.

Elvani, N., \& Linawati, N. (2013). Uji Konsistensi Kinerja Reksadana Saham Di Bursa Efek Indonesia Periode 2008-2012. Finesta, Vol. 1, No. 2, hlm. 130-135.

Fahmi, I. (2015). Manajemen Investasi Teori dan Soal Jawab, Edisi Kedua, Jakarta: Salemba Empat.

Halim, A. (2015). Analisis Investasi di Aset Keuangan, Edisi Pertama, Jakarta: Mitra Wacana Media.

Hartono, J. (2015). Teori Portofolio dan Analisis Investasi, Edisi Kesepuluh, Yogyakarta: BPFE-Yogyakarta.

Hendrawan, B. (2012). Portfolio Performance Evaluation Pada Reksadana Saham . Jurnal Integrasi, Vol. 4, No. 1, ISSN: 2085-3858, Hal. 61-67.

Paranita, C., Dzulkirom, M., \& Hidayat, R. R. (2015). Analisis Kinerja Investasi Dalam Reksadana Saham (Equity Funds) Dengan Metode Sharpe dan Treynor. Jurnal Administrasi Bisnis, Vol. 27, No. 1, Hal. 1-7.

Prajapati, K. P., \& Patel, M. K. (2012). Comparative Study On Performance Evaluation Of Mutual Fund Schemes Of Indian Companies. International Refereed Research Journal, Vol. 3, No. 3, ISSN: 2231-4172, Page. 47-59.

Qamruzzaman. (2014). Comparative Study On Performance Evaluation Of Mutual Fund Schemes In Bangladesh: An Analysis Of Monthly Returns. Journal Of Bussiness Studies Quarterly, Vol. 5(No. 4), ISSN: 2152-1034, Pages. 190-209.

Samsul, M. (2015). Pasar Modal \& Manajemen Portofolio, Edisi Kedua, Jakarta: Erlangga.

Santosa, M., \& Sjam, A. A. (2012). Penilaian Kinerja Produk Reksadana Dengan Menggunakan Metode Perhitungan Jensen Alpha, Sharpe Ratio, Treynor Ratio, M2, Dan Information Ratio. Jurnal Manajemen, Vol. 12, No. 1, Hal. 63-75.

Widoatmodjo, S. (2015). Pengetahuan Pasar Modal untuk Konteks Indonesia, Jakarta: PT Elex Media Komputindo. 